\title{
Sublethal effects of mercury and its distribution in the coral Porites astreoides
}

\author{
C. Bastidas*, E. M. García \\ Departamento Biología de Organismos, Universidad Simón Bolívar, Caracas 1080-A, Venezuela
}

\begin{abstract}
To study the effects of sublethal doses of mercury on corals, colonies of Porites astreoides (Lamarck) were exposed to nominal concentrations of 0.01, 0.1 and $0.5 \mathrm{mg} \mathrm{Hg}^{-1} \mathrm{using}$ semi-static, chronic bioassays for up to $15 \mathrm{~d}$, with $\mathrm{HgCl}_{2}$ administered by pulses every $3 \mathrm{~d}$ (mean concentration in the water was $0.004,0.037$ and $0.180 \mathrm{mg} \mathrm{Hg} \mathrm{l}^{-1}$, respectively). While total $\mathrm{Hg}$ in the corals was directly proportional to Hg exposure, analysis of the different coral compartments (polyps, zooxanthellae and skeleton) showed that zooxanthellae and the skeleton accumulated $\mathrm{Hg}$ in direct relation to $\mathrm{Hg}$ exposure, but polyp tissue accumulated more $\mathrm{Hg}$ at 0.1 than at $0.5 \mathrm{mg} \mathrm{Hg}^{-1}$. This suggests saturation of $\mathrm{Hg}$ only in polyps and/or activation of mechanisms of detoxification. Within a colony, the Hg concentration per unit area of coral surface differed between compartments as follows: zooxanthellae > polyp > skeleton. Colonies exposed to the highest Hg concentration accumulated $1.738 \mu \mathrm{g} \mathrm{Hg} \mathrm{cm}^{-2}, 89 \%$ of which was found in zooxanthellae, $7 \%$ in polyps and $4 \%$ in the skeleton. Polyp biomass (dry weight and protein content), zooxanthellae biomass (cell density and protein content), and pigment concentration per unit area of coral surface decreased with Hg exposure. The bioconcentration factor $([\mathrm{Hg}]$ in organism/[Hg] in water) was inversely related to the $\mathrm{Hg}$ concentration in water. The capacity of zooxanthellae and the skeleton to concentrate Hg and the decrease in zooxanthellae density support the hypothesis that polyps may divert $\mathrm{Hg}$ to these 2 coral compartments as a detoxifying mechanism.
\end{abstract}

KEY WORDS: Mercury $\cdot$ Bioconcentration $\cdot$ Bioassays $\cdot$ Sub-lethal exposure $\cdot$ Hard corals $\cdot$ Porites Caribbean

Resale or republication not permitted without written consent of the publisher

\section{INTRODUCTION}

The bioconcentration and toxic effects of heavy metals on many organisms in tropical marine environments are well established, yet these aspects have been little studied in coral reef organisms (Brown \& Howard 1985b, see Peters et al 1997 for a review). Studies of metal concentration in corals can be grouped into 3 categories. (1) The metal contents of different compartments have been studied to determine the distribution of the metal within the coral (Buddemeier et al. 1981, Howard \& Brown 1984, 1987, Brown \& Howard 1985a, Hanna \& Muir 1990, Brown et al. 1991, Bastidas \& García 1997, Esslemont et al. 2000). (2) The toxic effects of metals on coral physiology have been studied, mostly using copper (Mitchell
\& Chet 1975, Evans 1977, Howard et al. 1986) and, less often, iron (Harland \& Brown 1989). (3) Studies that have measured metal concentrations in corals, mostly as proxies for environmental concentrations (Goreau 1977, Brown \& Holley 1982, Denton \& Burdon-Jones 1986, Howard \& Brown 1987, Shen \& Boyle 1987, Shen et al. 1987, Glynn et al. 1989, Scott 1990, Guzmán \& Jiménez 1992, Guzmán \& Jarvis 1996, Bastidas \& García 1999, Guzmán \& García 2002). Altogether, these studies have broadened our knowledge of metal concentration in corals, but many aspects of the mechanisms of metal tolerance and detoxification remain uninvestigated.

Heavy metals are found in the environment from natural sources, but also from mining and other industrial activities. Among heavy metals, mercury is of par- 
ticular concern due to its extensive use in gold mining and its high toxicity (Lacher \& Goldstein 1997). It is estimated that atmospheric input of $\mathrm{Hg}$ has tripled over the past $150 \mathrm{yr}$, and that two-thirds of the current total is of anthropogenic origin, while one-third is from natural sources (Morel et al. 1998). On the west coast of Venezuela, Hg contamination has been a potential hazard for marine communities for several decades. Sources include a chlor-alkali plant, which operated in Golfo Triste until the mid-1970s (see Iglesias \& Penchaszadeh 1983, Pérez 1995 for further details), and an oil refinery and a petrochemical complex, which still operate here. This area is also affected by the discharge of various rivers with catchments encompassing agricultural lands. All these activities contribute to an increase in anthropogenic sources of metals, and $\mathrm{Hg}$ in particular. At the western end of Golfo Triste, $\mathrm{Hg}$ levels in seawater, marine invertebrates, seagrasses and the sediments at the coral reefs of Parque Nacional Morrocoy (Iglesias \& Penchaszadeh 1983, Pérez 1995, García et al. 1998, Bastidas \& García 1999, Bastidas et al. 1999) indicated that the knowledge of $\mathrm{Hg}$ concentration and its sublethal effects on organisms is of special relevance to the management of nearby marine protected areas.

In the marine environment, $\mathrm{Hg}$ concentrations have been reported for algae, plants and animals (e.g. Sorensen \& Bjerregaard 1991, García 1993, Palmer \& Presley 1993, 1996, Rossi et al. 1993, Allen 1994, Bianchini \& Gilles 1996, García \& Reyes 1996, Herut et al. 1996, Pergent \& Pergent-Martini 1999). However, there is an incomplete understanding of the factors that control the bioconcentration of $\mathrm{Hg}$ in aquatic systems (Morel et al. 1998). For this, bioassays or toxicity tests in the laboratory are useful, as they allow the establishment of cause-and-effect relationships more easily than in natural conditions. In particular, chronic toxicity tests allow the measurement of the sublethal effects of a contaminant, and their results can provide insights into the regulatory mechanisms taking place in the presence of that contaminant (e.g. Rand et al. 1995). For corals in particular, studies of mercury concentration are scarce, and there is no investigation examining $\mathrm{Hg}$ effects in coral physiological conditions. The present study aimed to determine (1) the bioconcentration of $\mathrm{Hg}$ by adult colonies of the coral Porites astreoides, (2) the distribution of $\mathrm{Hg}$ among the coral compartments (polyps, zooxanthellae and skeleton), and (3) the sublethal effects of $\mathrm{Hg}$ on this species.

\section{MATERIALS AND METHODS}

General procedures and treatments. Colonies of Porites astreoides (green morph) were collected using a hammer and a chisel from a 1 to $1.5 \mathrm{~m}$ deep reef flat at Bajo Caimán, Parque Nacional Morrocoy, Venezuela $\left(10^{\circ} 52^{\prime} \mathrm{N}, 69^{\circ} 16^{\prime} \mathrm{W}\right)$. This species is commonly found at this site with a mean density of 0.78 colonies $\mathrm{m}^{-2}( \pm 0.35 \mathrm{SD}$, evaluated using 6 belt transects of $50 \times$ $1 \mathrm{~m})$. Collected colonies ranged in size from 41 to $129 \mathrm{~cm}^{2}$, with a mean surface area of $80 \mathrm{~cm}^{2}$. The corals were transported to the laboratory in $40 \mathrm{l}$ seawater containers within $2 \mathrm{~h}$ of collection. We removed as many of the dead sections of the corals as possible, and the colonies were thoroughly cleaned of associated biota (e.g. zoanthids, algae, polychaetes). Prior to the bioassays, corals were allowed to acclimate outdoors in aerated tanks for 10 to $20 \mathrm{~d}$, by which time liberation of planulae and profuse mucus production had ceased.

Two semi-static bioassays (i.e. with water renewal every $3 \mathrm{~d}$ ) were carried out for 11 and $15 \mathrm{~d}$ (hereafter referred to as Bioassay I and II, respectively). We undertook 2 independent bioassays to provide an indication of the reproducibility of the results. For each bioassay, 3 coral colonies were used as replicates in each of the 4 following nominal concentrations: $0,0.01,0.1$ and $0.5 \mathrm{mg} \mathrm{Hg} \mathrm{l}^{-1}$. These levels of exposure will be hereafter referred to as $\mathrm{C}_{\mathrm{f}}, \mathrm{T}_{0.01}, \mathrm{~T}_{0.1}$ and $\mathrm{T}_{0.5}$. To obtain these concentrations, $\mathrm{HgCl}_{2}$ (AnalaR) from a stock solution was administered directly to the aquaria with each seawater renewal. Additionally, 3 colonies were taken as field controls $(\mathrm{F})$, and 3 colonies as controls at the beginning of the bioassay $\left(\mathrm{C}_{\mathrm{i}}\right)$. These control colonies were used to evaluate the potential changes in the corals during the acclimatization period ( $\mathrm{F}$ vs $\mathrm{C}_{\mathrm{i}}$ ), and during the bioassay $\left(C_{i}\right.$ vs $\left.C_{f}\right)$, without the effects of $\mathrm{Hg}$.

For the bioassays, the corals were placed individually in 3.51 Plexiglass aquaria with seawater filtered through fiber glass, activated carbon, phytoplankton net, Whatman no. 1 filter paper, and a $0.45 \mu \mathrm{m}$ filter, in that order. Each coral rested on a PVC base with a stirrer bar underneath to maintain water circulation (e.g. Schlichter \& Fricke 1991). The aquaria were not aerated during the bioassays, and were covered with translucent plastic to minimize water evaporation. Under this plastic cover, the corals received indoor sunlight and additional artificial light (photoperiod 12:12 h light:dark) for a total irradiance of 90 to $140 \mu \mathrm{E}$ $\mathrm{m}^{-2} \mathrm{~s}^{-1}$ (LiCor LI-185 quantum radiometer/photometer). The corals were not fed during the bioassays.

The temperature, dissolved oxygen, $\mathrm{pH}$, and salinity were monitored daily. The ranges of these parameters in the aquaria water were 27 to $29^{\circ} \mathrm{C}, 4.25$ to $7.20 \mathrm{mg} \mathrm{l}^{-1}$, pH 6.74 to 8.20 , and 36 to 38 ppt, respectively. After each renewal the water in the aquaria was slightly colder, better aerated and more alkaline compared with the same water after $72 \mathrm{~h}$. The following qualitative characters of colony health were monitored throughout the duration of the bioassays: color, polyp 
expansion/retraction, bleached areas, mucous sheet, and algal growth. When totally bleached, the condition of the colonies was difficult to evaluate. A colony was considered dead when it showed total bleaching and tissue loss accompanied by an increased turbidity in the water.

Mercury analyses. Total $\mathrm{Hg}$ content was measured in both the coral and the seawater of each aquarium replicate. Mercury analysis was performed largely using the methods of Guzmán \& García (2002). The coral samples, including polyp tissue, zooxanthellae and skeleton, were acid digested for $6 \mathrm{~h}$ in a water bath $\left(59^{\circ} \mathrm{C}\right)$, but digestion procedures were not used for the water samples. Mercury content was measured by atomic absorption spectrometry (Perkin-Elmer 2380), using the cold-vapor technique with a detection limit of $2 \mathrm{ppb}$ (APHA 1992). High-quality acids (Riedel-de Haen) and the appropriate blanks were used for the $\mathrm{Hg}$ analyses.

Water samples: Prior to the bioassays, the Hg loss in the absence of corals was estimated from duplicate water samples taken from an aquarium, with an initial nominal concentration of $0.1 \mathrm{mg} \mathrm{l}^{-1}$ at $0,1,3,6,12,24$, 36,48 and $72 \mathrm{~h}$. This assay indicated that up to $50 \%$ of the initial concentration of $\mathrm{Hg}$ was lost after $24 \mathrm{~h}$, and $90 \%$ after $72 \mathrm{~h}$. Based on this result, Hg was added with each water renewal after $72 \mathrm{~h}$ to maintain the nominal concentration. In the aerobic conditions of the aquaria, Hg losses were likely attributable to adsorption to organic matter and to volatilization, rather than to its methylation (Morel et al. 1998). To determine Hg concentration in water during the bioassays, a $100 \mathrm{ml}$ sample was taken every $24 \mathrm{~h}$ from each aquarium. These samples were preserved, using $0.5 \mathrm{ml} \mathrm{HNO}_{3}$, followed by freezing until $\mathrm{Hg}$ determination (e.g. Blust et al. 1995). To estimate the $\mathrm{Hg}$ content in suspended solids, two $500 \mathrm{ml}$ water samples were filtered (preweighed, $0.45 \mu \mathrm{m}$ Millipore) from each aquarium at the end of each bioassay. Filters containing the suspended solids were weighed (wet) and digested to determine the $\mathrm{Hg}$ content.

Polyp tissue: At the end of the bioassays, coral tissue was removed from each colony using a water-pik (Johannes \& Wiebe 1970) operated with $0.45 \mu \mathrm{m}$ filtered sea water (FSW). Corals were processed in order of increasing $\mathrm{Hg}$ exposure, starting with the controls. The water-pik was cleaned with FSW and diluted nitric acid after processing each colony. The blastate was homogenized and phosphate buffer $(5 \mathrm{M}, \mathrm{pH} 7.6)$ was added for a final buffer concentration of $0.1 \mathrm{M}$ (e.g. Gattuso et al. 1993). The homogenate was centrifuged at $500 \times g$ for $20 \mathrm{~min}$ and the supernatant was regarded as containing polyp tissue after microscopic verification of the absence of zooxanthellae. Triplicate $50 \mathrm{ml}$ aliquots of the supernatant were taken for each colony, weighed and digested with $3 \mathrm{ml} \mathrm{HNO}_{3}$ and $1.5 \mathrm{ml}$ $\mathrm{H}_{2} \mathrm{SO}_{4}$ to determine the $\mathrm{Hg}$ content of the polyp tissue.

Zooxanthellae: The zooxanthellae pellet was resuspended in $0.02 \%$ SDS (sodium dodecyl sulfate, BioRad 161-0301), centrifuged at $500 \times g$ for $20 \mathrm{~min}$ and then washed with $0.1 \mathrm{M}$ phosphate buffer. This cleaning procedure was repeated 4 times to assure the complete removal of polyp tissue (McAuley 1986, Lesser \& Shick 1989, Lesser et al. 1990). The final pellet was resuspended to attain a volume of 15 to $25 \mathrm{ml}$ with phosphate buffer. For $\mathrm{Hg}$ analyses, we took triplicate aliquots of $3 \mathrm{ml}$ for each colony, weighed them and added $1.5 \mathrm{ml} \mathrm{HNO}_{3}$ and $1.5 \mathrm{ml} \mathrm{H}_{2} \mathrm{SO}_{4}$ for the digestion.

Coral skeleton: After tissue elimination, the area of each colony was estimated using the aluminum foil method (Marsh 1970). The skeleton was bathed in a sodium hypochlorite solution (5\%) for $5 \mathrm{~d}$ and then was sonicated for $4 \mathrm{~h}$ to eliminate the remaining tissue. Each colony was dried in an incubator at $50^{\circ} \mathrm{C}$ for $3 \mathrm{wk}$. After this, the surface skeleton was removed by rubbing the coral with a benchtop drill press until the corallite walls were removed, or until the base of the corallite was visible. Using this procedure the most superficial skeleton in contact with the polyp tissue was obtained from each colony. The amount of skeleton removed from each colony was directly correlated with its area (Pearson, $r=0.68$ ), indicating that the corals were rubbed to approximately the same depth from the original skeleton surface. For each colony, duplicates of 1 to $2 \mathrm{~g}$ of the skeleton powder were digested with $5 \mathrm{ml} \mathrm{HNO}_{3}$ : water (1:1) and $1 \mathrm{ml}$ of concentrated $\mathrm{HNO}_{3}$. To estimate any remaining tissue in the skeleton, 1 to $2 \mathrm{~g}$ of skeleton powder were used to determine the organic matter content by the WalkleyBlack method (Jackson 1970). The organic content of the skeleton was relatively low, with an average of $0.63 \%( \pm 0.37 \mathrm{SD}, \mathrm{n}=14)$ and a maximum of $1.15 \%$, indicating that the cleaning procedure was acceptable. Thus, we are confident that any contribution of the polyp tissue to the $\mathrm{Hg}$ content of the skeleton was negligible.

Physiological parameters. For pigment analyses, 1.5 to $2.5 \mathrm{ml}$ of the final suspension of zooxanthellae were subsampled and centrifuged. For pigment extraction the zooxanthellae pellets were resuspended in chilled acetone in the dark at $-20^{\circ} \mathrm{C}$ for a maximum of $20 \mathrm{~h}$. Extracts were centrifuged at $15000 \times g$ for $10 \mathrm{~min}$ and diluted with FSW to $90 \%$ acetone; the absorbance of the supernatant was read immediately at $750,665,663$, 645, 630, 510 and $480 \mathrm{~nm}$ using an Hitachi 100-60 spectrophotometer. The amounts of chlorophyll (chl) a and $C$ were calculated using the equations of SCOR-UNESCO (1966), and the amounts of carotenoids were estimated as in Parsons \& Strickland (1963). The zooxanthellae density was determined in 
6 to 10 subsamples of the final algal suspension using a Neubauer haemocytometer. The protein content of triplicate $100 \mu \mathrm{l}$ subsamples of the final suspension was determined using the Bradford (1976) procedure, with a $5 \mathrm{mg} \mathrm{ml}^{-1}$ stock solution of bovine serum albumin (BSA) as standard for the calibration curve.

The biomass of the polyp tissue was determined as dry weight and protein content. The dry weight was determined from triplicate subsamples of the homogenized tissue that were dried in an oven at $60^{\circ} \mathrm{C}$ to constant weight. The protein determination was conducted as above using a BSA stock solution of $50 \mu \mathrm{g}$ $\mathrm{ml}^{-1}$ for the calibration curve. To determine changes in weight, as a proxy for colony growth (Davies 1989), each colony was weighed in water both at the beginning and the end of the bioassay.

Variables and statistical analysis. The bioassays had 6 treatment levels: field control $(\mathrm{F})$, control at the beginning of the bioassay $\left(\mathrm{C}_{\mathrm{i}}\right)$, control at the end of the bioassay $\left(\mathrm{C}_{\mathrm{f}}\right)$, and $0.01\left(\mathrm{~T}_{0.01}\right), 0.1\left(\mathrm{~T}_{0.1}\right)$ and $0.5 \mathrm{mg} \mathrm{Hg}$ $\mathrm{l}^{-1}\left(\mathrm{~T}_{0.5}\right)$. The 2 bioassays were treated as blocks under the ANOVA analysis, and the following variables required logarithmic transformation for their normalization: $\mathrm{Hg}$ in skeleton per unit area of coral surface, $\mathrm{Hg}$ per zooxanthella, $\mathrm{Hg}$ in suspended solids, dry weight, chl $a$ and $c$ per cell, and $\operatorname{chl} c$ per unit area of coral surface. Despite attaining a normal distribution, the data for $\mathrm{Hg}$ content in polyp, in skeleton (per weight) and in zooxanthellae (per area and per protein) were heteroscedastic. A Kruskal-Wallis test was used, pooling the replicates from both bioassays, when data normalization was not achieved.

Mercury concentration expressed per unit surface area was the preferred parameter to allow comparisons among all 3 coral compartments. The standardization of $\mathrm{Hg}$ content per mg protein impeded the comparisons with the coral skeleton. An alternative to the expression of $\mathrm{Hg}$ per unit surface area was to use $\mathrm{Hg}$ per unit weight for all coral compartments. Although we reported $\mathrm{Hg}$ per unit weight for polyps and the skeleton for potential comparison with other studies, the sample volume of zooxanthellae was insufficient to estimate their $\mathrm{Hg}$ content per weight in addition to all other estimates.

\section{RESULTS}

\section{Mercury content in water and suspended solids}

The Hg concentration in the water during the bioassays was variable as a result of the $\mathrm{Hg}$ losses and its pulsed administration. Due to this variability, the corals were exposed to a lower concentration than the nominal concentration for each exposure level. Thus, the weighted average of the concentrations measured in water was a superior indicator of the actual exposure of corals to $\mathrm{Hg}$ than was the nominal concentration (Table 1). The Hg content of the suspended solids in the water was directly related to the exposure concentration (Table 2). Of the total Hg added to the aquaria, up to $10 \%$ was associated with the suspended solids in the water after $72 \mathrm{~h}$. The amount of suspended solids in water, ranging from 0.260 to $0.616 \mathrm{~g} \mathrm{l}^{-1}$ (wet weight), was also directly related to the $\mathrm{Hg}$ concentration (ANOVA $\mathrm{p}<0.001$ ).

\section{Mercury content in coral: polyp tissue, zooxanthellae and skeleton}

Total $\mathrm{Hg}$ concentration in the coral, expressed as the sum of the concentrations in the 3 compartments per unit of coral surface area, was directly proportional to the $\mathrm{Hg}$ concentration in the water (KruskalWallis, $\mathrm{p}<0.001)$. The Hg concentrations in zooxan-

Table 1. Mercury concentration in the water of the aquaria $\left(\mathrm{mg} \mathrm{l}^{-1}\right.$, mean $\pm \mathrm{SD}$ ) measured every $24 \mathrm{~h}$, for each treatment ( $\mathrm{T}_{i} 0.01,0.1,0.5 \mathrm{mg} \mathrm{Hg}^{-1}$ ) and each bioassay (I and II described in 'Materials and methods'. WA: weighted average. $\mathrm{N}$ : number of times (in d) the colonies were assayed under the 0,24 or $48 \mathrm{~h}$ conditions

\begin{tabular}{|c|c|c|c|c|}
\hline (h) & & $\mathrm{T}_{0.01}$ & $\mathrm{~T}_{0.1}$ & $\mathrm{~T}_{0.5}$ \\
\hline \multicolumn{5}{|c|}{ Bioassay I } \\
\hline 0 & 4 & $0.007 \pm 0.002$ & $0.073 \pm 0.016$ & $0.442 \pm 0.113$ \\
\hline 24 & 4 & $0.003 \pm 0.001$ & $0.028 \pm 0.012$ & $0.205 \pm 0.099$ \\
\hline 48 & 3 & $0.002 \pm 0.003$ & $0.010 \pm 0.004$ & $0.050 \pm 0.016$ \\
\hline 72 & & $0.001 \pm 0.001$ & $0.006 \pm 0.004$ & $0.028 \pm 0.024$ \\
\hline WA & & 0.004 & 0.039 & 0.249 \\
\hline \multicolumn{5}{|c|}{ Bioassay II } \\
\hline 0 & 5 & $0.006 \pm 0.002$ & $0.084 \pm 0.039$ & $0.298 \pm 0.071$ \\
\hline 24 & 5 & $0.001 \pm 0.001$ & $0.013 \pm 0.009$ & $0.095 \pm 0.035$ \\
\hline 48 & 5 & $0.001 \pm 0.001$ & $0.008 \pm 0.011$ & $0.023 \pm 0.012$ \\
\hline 72 & & $0.000 \pm 0.001$ & $0.008 \pm 0.008$ & $0.007 \pm 0.005$ \\
\hline WA & & 0.003 & 0.035 & 0.111 \\
\hline
\end{tabular}

Table 2. Mercury concentration in suspended solids ( $\mu \mathrm{g} \mathrm{Hg}$ $g$ wet weight ${ }^{-1}$, mean $\pm \mathrm{SE}$ ) from the seawater in the aquaria. $\mathrm{T}_{0.01}, \mathrm{~T}_{0.1}$, and $\mathrm{T}_{0.5}$ are treatments at $0.01,0.1$ and $0.5 \mathrm{mg} \mathrm{Hg}$ $1^{-1}$, respectively

\begin{tabular}{|lcc|}
\hline Treatment & $\mathrm{N}$ & {$[\mathrm{Hg}]$ in solids } \\
\hline Control & 6 & $0.675 \pm 0.171$ \\
$\mathrm{~T}_{0.01}$ & 6 & $1.695 \pm 0.336$ \\
$\mathrm{~T}_{0.1}$ & 6 & $12.312 \pm 6.738$ \\
$\mathrm{~T}_{0.5}$ & 6 & $41.882 \pm 17.098$ \\
\hline
\end{tabular}




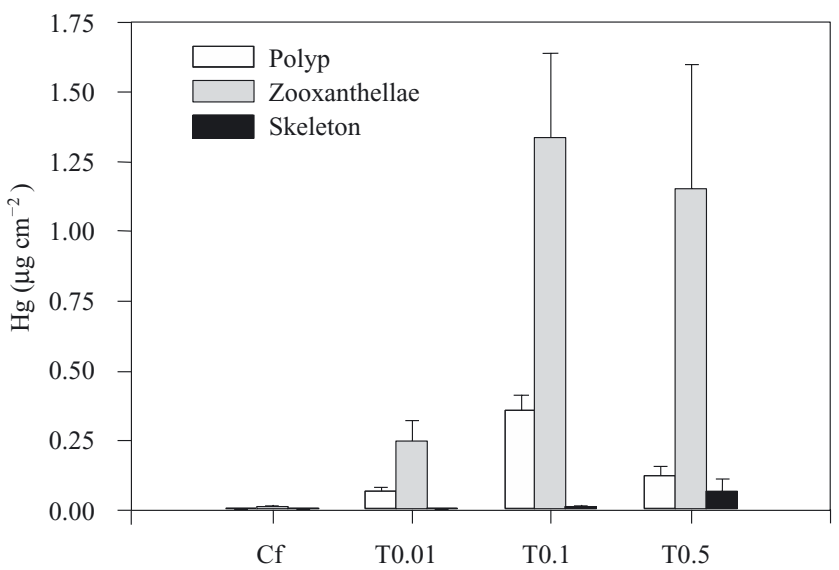

Fig. 1. Porites astreoides. $\mathrm{Hg}$ concentration per unit coral surface area for each coral compartment-polyp tissue, zooxanthellae, skeleton - and for each treatment (mean $\pm \mathrm{SE}$ )

thellae and in the skeleton were also directly related to the $\mathrm{Hg}$ concentration in the water. However, the $\mathrm{Hg}$ concentration in polyp tissue was larger at $\mathrm{T}_{0.1}$ than at $\mathrm{T}_{0.5}$ (Fig. 1). Other forms of expressing the $\mathrm{Hg}$ content were consistent with these results of $\mathrm{Hg}$ per unit of surface area. For example, the $\mathrm{Hg}$ per unit of dry weight of skeleton was directly related with exposure, being 6 times higher for colonies at $\mathrm{T}_{0.5}$ than at $\mathrm{T}_{0.1}(1.270 \pm 0.809$ vs $0.221 \pm 0.100 \mu \mathrm{g} \mathrm{Hg}$ $\mathrm{g}$ dry weight ${ }^{-1}$ ); in contrast, $\mathrm{Hg}$ in polyps of colonies at $\mathrm{T}_{0.1}$ was 2.5 times that of colonies at $\mathrm{T}_{0.5}(2.517 \pm$ 0.371 vs $0.994 \pm 0.353 \mu \mathrm{g} \mathrm{Hg} g$ dry weight ${ }^{-1}$ ). Also, the $\mathrm{Hg}$ per number of zooxanthellae showed a direct relationship with $\mathrm{Hg}$ exposure (ANOVA, p $<0.001$, Table 3), as it occurred for $\mathrm{Hg}$ per unit area of coral surface.

Among coral compartments, $\mathrm{Hg}$ concentration in the zooxanthellae was found to be much higher than that in the polyps and the skeleton within each coral colony (paired Wilcoxon with ranks $\mathrm{p}<0.001$ ). Despite these differences, the $\mathrm{Hg}$ content was directly correlated

Table 3. Porites astreoides. Mercury concentration per number of zooxanthellae ( $\mu \mathrm{g} \mathrm{Hg} 10^{6}$ cells $^{-1} ; \mathrm{N}=6$, mean $\pm \mathrm{SE}$ ). $\mathrm{F}$ : field control; $\mathrm{C}_{\mathrm{i}}$ and $\mathrm{C}_{\mathrm{f}}$ : controls at the beginning and at the end of the bioassays, respectively. $\mathrm{T}_{0.01}, \mathrm{~T}_{0.1}, \mathrm{~T}_{0.5}$ are treatments at $0.01,0.1$ and $0.5 \mathrm{mg} \mathrm{Hg} \mathrm{l}^{-1}$, respectively

\begin{tabular}{|lc|}
\hline Treatment & {$[\mathrm{Hg}]$ in zooxanthellae } \\
\hline $\mathrm{F}$ & $0.002 \pm 0.001$ \\
$\mathrm{C}_{\mathrm{i}}$ & $0.000 \pm 0.000$ \\
$\mathrm{C}_{\mathrm{f}}$ & $0.004 \pm 0.002$ \\
$\mathrm{~T}_{0.01}$ & $0.090 \pm 0.028$ \\
$\mathrm{~T}_{0.1}$ & $0.486 \pm 0.142$ \\
$\mathrm{~T}_{0.5}$ & $0.926 \pm 0.452$ \\
\hline
\end{tabular}

among the 3 coral compartments within a colony. There was a larger correlation in Hg content between zooxanthellae and polyps than between each of these 2 compartments and the skeleton (Spearman's $\rho$ : polyps-zooxanthellae $=0.893$, polyps-skeleton $=$ 0.464, zooxanthellae-skeleton $=0.562$ ).

The bioconcentration factor $(\mathrm{BCF}=[\mathrm{Hg}]$ coral compartment/[Hg] water) was inversely proportional to the $\mathrm{Hg}$ concentration in water for zooxanthellae and polyp compartments, but not for the skeleton (Fig. 2). Consistent with the $\mathrm{Hg}$ concentration among the coral compartments, the BCF was greater for zooxanthellae compared to polyps and skeleton (maximum of 83, 21 and 1 , respectively).

\section{General condition of the colonies during the bioassays}

During the bioassays we observed that (1) changes in colony color occurred slower than polyp expansion/contraction, (2) the color of most colonies became darker (except those at $\mathrm{T}_{0.5}$ ), and (3) the presence of total or partial mucous sheets over the colonies was common, and they often peeled off the colony surface. Some of the colonies at $\mathrm{T}_{0.5}$ showed the most striking changes: polyp contraction within the first $8 \mathrm{~h}$, and color and tissue loss within the first 24 and $48 \mathrm{~h}$ of $\mathrm{Hg}$ exposure, respectively. Also, at this $\mathrm{Hg}$ concentration, 3 out of 6 colonies died in $72 \mathrm{~h}$ (1 from Bioassay I and 2 from Bioassay II). Therefore, while in all other treatments colonies survived until the end of the bioassays, only 3 colonies at $\mathrm{T}_{0.05}$ did. Thus, a nominal $\mathrm{Hg}$ concentration in water between 0.037 and $0.180 \mathrm{mg} \mathrm{l}^{-1}$ could be considered as the lethal concentration $\left(\mathrm{LC}_{50}-72 \mathrm{~h}\right)$ for the coral Porites astreoides.

\section{Physiological parameters}

The polyp biomass decreased significantly in colonies exposed to $\mathrm{Hg}$, with the protein content being more sensitive to $\mathrm{Hg}$ concentration than the dry weight ( $p=0.005$ and $p=0.025$, respectively; Fig. 3). The weight increment of the colonies during the bioassays tended to be inversely related to the $\mathrm{Hg}$ in water (Table 4). However, these differences among Hg treatments lacked statistical significance due to the high variability among colonies in the same treatment and to the relatively small sample sizes.

The zooxanthellae density was highest in control colonies at the beginning of the bioassays $(3.66 \pm 0.46 \times$ $10^{6}$ cells $\mathrm{cm}^{-2}$ in $\mathrm{Ci}$ ) and lowest in colonies at $\mathrm{T}_{0.5}$ (ANOVA, p < 0.05; Fig. 4). Also, the zooxanthellae pro- 

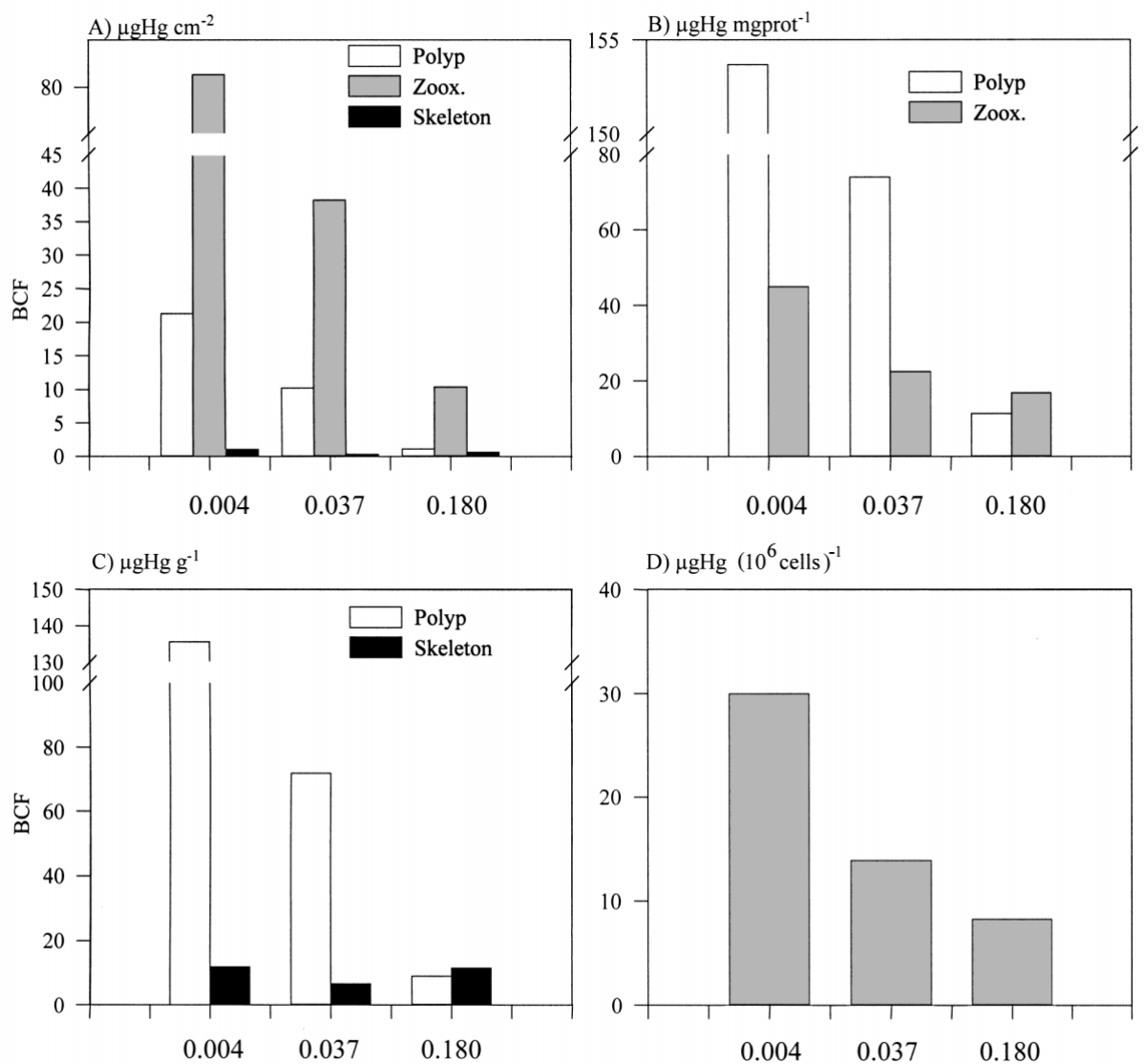

Fig. 2. Porites astreoides. Bioconcentration factor $(\mathrm{BCF}=[\mathrm{Hg}]$ in compartment/[Hg] in water) of polyp, zooxanthellae (zoox.) and skeleton. $x$-axis shows the average measured $H g$ concentration in the aquaria water for $\mathrm{T}_{0.01}, \mathrm{~T}_{0.1}$, and $\mathrm{T}_{0.5}$. (A) based on colony area, (B) based on protein (prot) content, (C) based on dry weight and (D) based on zooxanthellae number

Table 4. Porites astreoides. Change in weight $\left(\mathrm{g} \mathrm{d}^{-1}\right.$, mean \pm $\mathrm{SD})$ of the colonies during the bioassays. See Table 3 for description of treatments

\begin{tabular}{|lcr|}
\hline Treatment & $\mathrm{N}$ & Change in weight \\
\hline Control & 5 & $0.138 \pm 0.154$ \\
$\mathrm{~T}_{0.01}$ & 5 & $0.064 \pm 0.601$ \\
$\mathrm{~T}_{0.1}$ & 6 & $-0.016 \pm 0.307$ \\
$\mathrm{~T}_{0.5}$ & 3 & $-0.007 \pm 0.120$ \\
\hline
\end{tabular}

tein content per unit area and per cell decreased with increasing $\mathrm{Hg}$ concentration in the water (ANOVA p < 0.05 and Kruskal-Wallis p < 0.05, respectively; Fig. 5). The pigment content of zooxanthellae per unit area varied among levels of $\mathrm{Hg}$ exposure (ANOVA $\mathrm{p}<$ $0.001,0.05$, and 0.001 for $\mathrm{chl} a, \mathrm{chl} c$ and carotenoids respectively, Fig. 6a), but this resulted mostly from the decrease in zooxanthellae density, as the pigment content per cell remained similar among treatments (Fig. 6b).

\section{DISCUSSION}

We evaluated the bioconcentration of mercury in the coral Porites astreoides and the effect of this heavy metal on the coral physiology, using semi-static bioassays with sublethal levels of $\mathrm{Hg}(0.004$ to $0.180 \mathrm{mg}$ $\mathrm{l}^{-1}$ ). After a maximum of $15 \mathrm{~d}$ exposure, coral colonies accumulated $\mathrm{Hg}$ with total concentration being directly related to exposure concentration, and their overall physiological condition declined.

Among the coral compartments, the Hg content per unit surface area differed as follows: zooxanthellae > polyp > skeleton, for all $\mathrm{Hg}$ treatments. Colonies exposed to the highest $\mathrm{Hg}$ concentration accumulated a total of $1.738 \mu \mathrm{g} \mathrm{Hg} \mathrm{cm}^{-2}, 89 \%$ of which was in the zooxanthellae, $7 \%$ in the polyps, and $4 \%$ in the skeleton. A higher metal content in the coral tissue (polyp + zooxanthellae) than in the skeleton has previously been observed (Brown \& Howard 1985a, Howard \& Brown 1987, Hanna \& Muir 1990, Bastidas \& García 1997, Esslemont et al. 2000). For other organisms with carbonate structures, such as otoliths, 


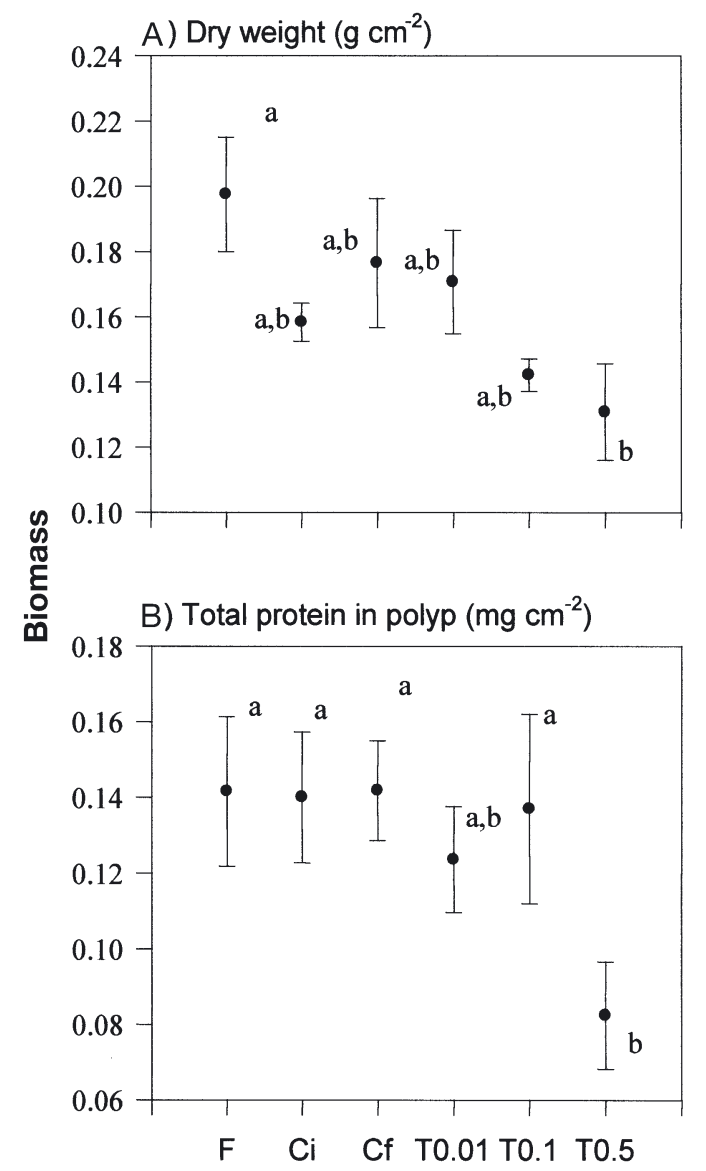

Fig. 3. Porites astreoides. Polyp-biomass parameters during the bioassays: (A) dry weight and (B) total protein. Different letters indicate significant differences $(p<0.05)$ among treatments. F: field controli $\mathrm{C}_{\mathrm{i}}$ and $\mathrm{C}_{\mathrm{f}}$ : controls at beginning and end of bioassays, respectively; $\mathrm{T}_{0.01}, \mathrm{~T}_{0.1}$ and $\mathrm{T}_{0.5}$ : treatments at $0.01,0.1$, and $0.5 \mathrm{mg} \mathrm{Hg} \mathrm{l}^{-1}$, respectively

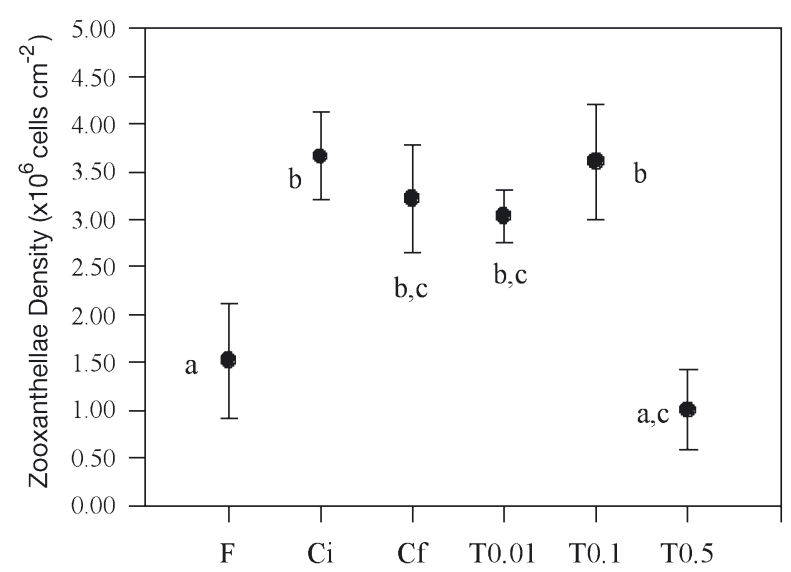

Fig. 4. Porites astreoides. Zooxanthellae density $(\mathrm{N}=6$, mean \pm SE). Different letters indicate significant differences $(p<0.05)$ among treatments. For abbreviations see Fig. 3 tissue also showed higher content of trace metals than did hard body parts (e.g. Geffen et al. 1998 and references therein).

Many studies have compared metal concentration in hard and soft body parts, but studies discriminating among soft body tissues are relatively few. In the present study, zooxanthellae accumulated higher concentration of $\mathrm{Hg}$ than the polyp tissue of Porites astreoides. This may have resulted from the high density of zooxanthellae, their higher protein contribution per unit coral surface area compared to polyps, and/or their high metabolic rate. This finding agrees with a similar study using copper, in which the metal concentration in zooxanthellae alone was double that of tissue plus zooxanthellae in the anemone Anemonia viridis (Harland \& Nganro 1990). However, out of 4 alkaline metals (Mg, Ca, Sr, Ba), Buddemeier et al. (1981) found that only Ba was in higher concentration in the zooxanthellae than in the polyps of several scleractinian species. Also, in the clam Tridacna crocea, the zooxanthellae had a relatively low metal concentrations com-
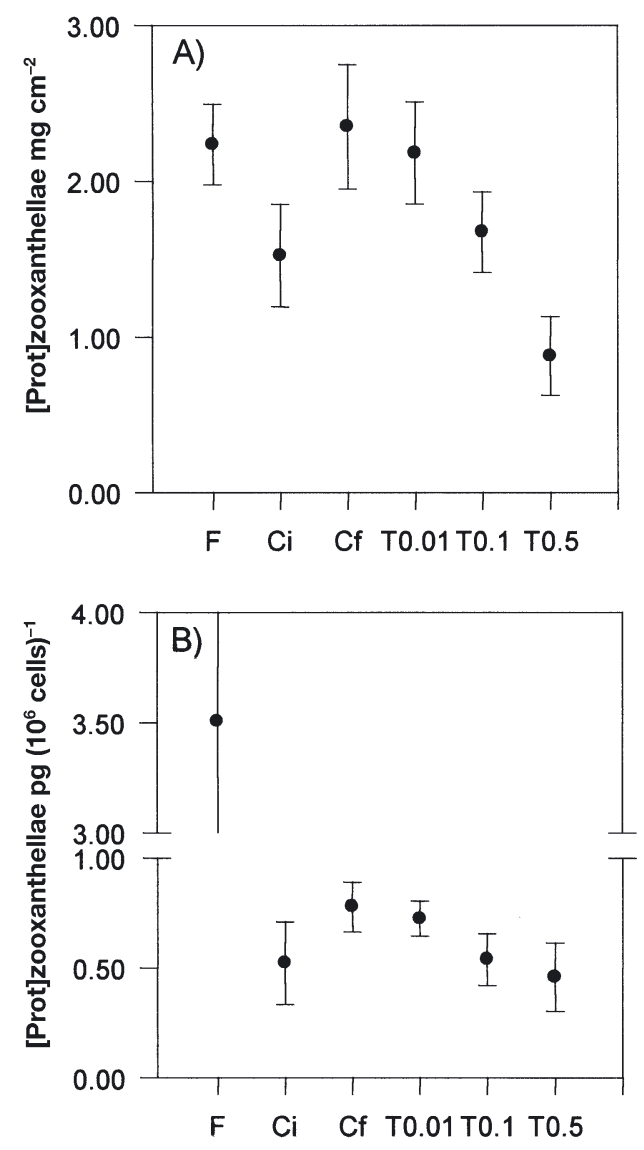

Fig. 5. Porites astreoides. Zooxanthellae protein (prot) content for both bioassays $(\mathrm{N}=6$, mean $\pm \mathrm{SE}$ ), (A) based on colony area and (B) based on cell number. For abbreviations see Fig. 3 
pared with the mantle tissue after exposure to $\mathrm{Cd}$ and to $\mathrm{Cu}$ (Duquesne \& Coll 1995). These mixed results suggest that the distribution of metals among living compartments of symbiotic organisms may vary largely depending on the characteristics of the metal and its potential physiological role in the species.

Despite the large contribution of zooxanthellae to $\mathrm{Hg}$ concentration in Porites astreoides, the $\mathrm{BCF}$ of the zooxanthellae was at the lower end of the range of similar unicellular organisms $\left(254-1.6 \times 10^{5}\right.$ for $\mathrm{Zn}$, $39-6.9 \times 10^{5}$ for $\mathrm{Cu}$, and up to $1.2 \times 10^{6}$ for $\mathrm{Pb}$; Lewis 1995). A low BCF may result from a high growth rate, which may produce a high elimination rate, and/or from a reduction in the cell membrane permeability (Lewis 1995). The intracellular symbiosis of the zooxanthellae in the coral polyp may have affected the metal availability, potentially reducing its BCF. The polyp host may control the availability of $\mathrm{Hg}$ to the

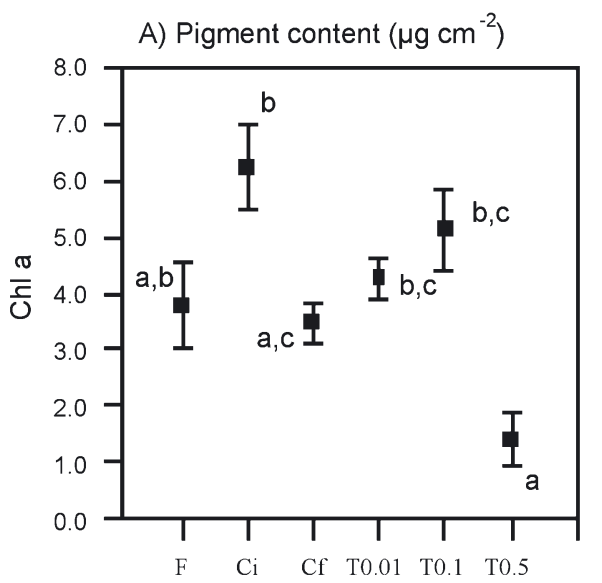

B) Pigment content $\left(\mathrm{pg} \mathrm{cell}^{-1}\right)$
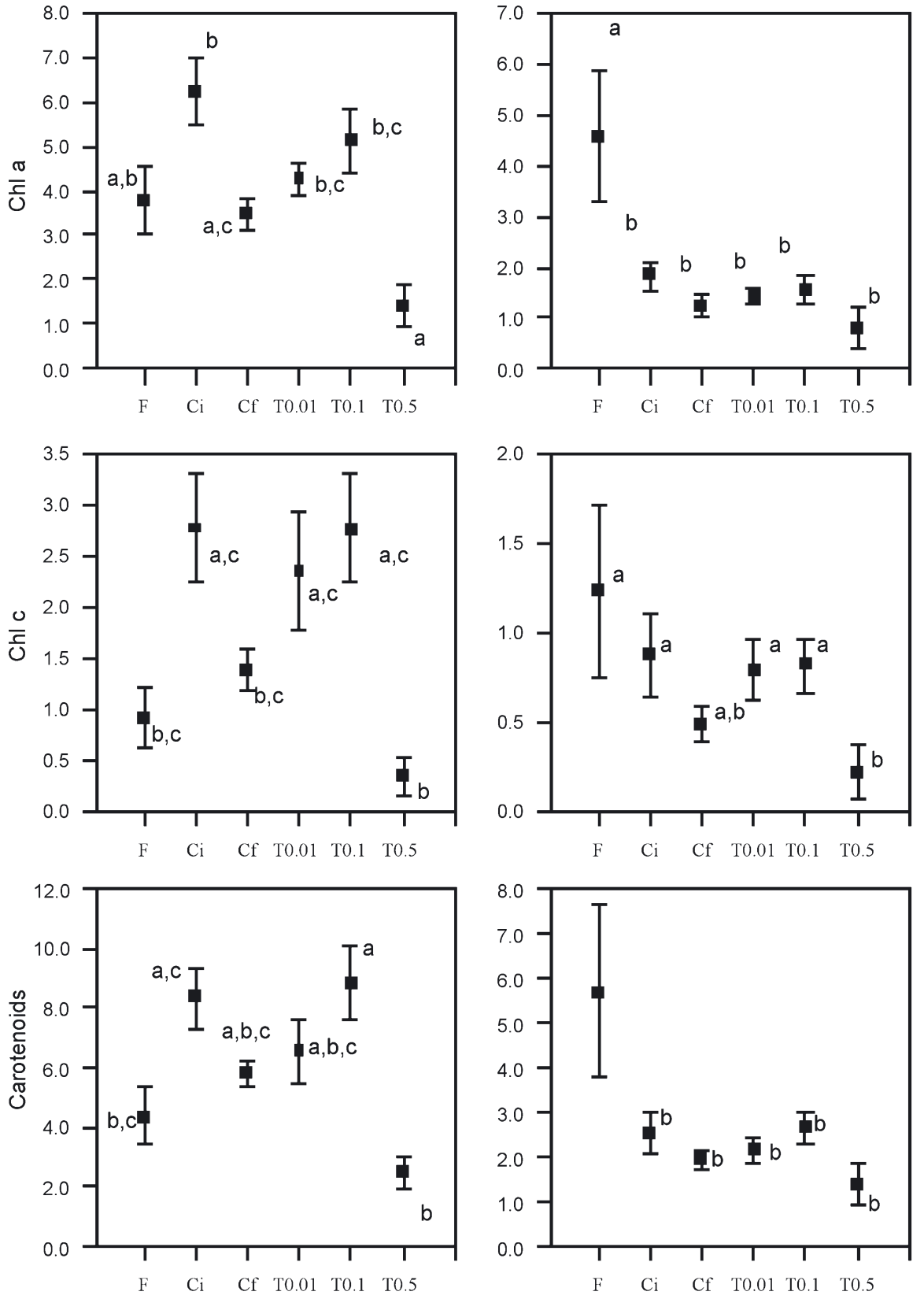

Fig. 6. Porites astreoides. Zooxanthellae pigment content (chl $a, \mathrm{chl} c$ and carotenoids), (A) based on coral surface area ( $\mathrm{N}=6$, mean $\pm \mathrm{SE}$ ) and $(\mathrm{B})$ per cell $(\mathrm{N}=6$, mean $\pm \mathrm{SE})$. For abbreviations see Fig. 3 
zooxanthellae, as it does with the charged forms of inorganic nutrients (e.g. Miller \& Yellowlees 1989). However, the BCF of $\mathrm{Hg}$ in the free-living alga Acetabularia calyculus was similar (40 to 140 for up to $1 \mathrm{ppm}$ and 7 d of exposure; García 1993, García \& Reyes 1996) to that obtained here for the zooxanthellae ( 2 to 83 for up to $0.5 \mathrm{ppm})$. Thus, it remains to be investigated whether differences in the BCF among species result from the symbiotic condition of the organism or from the metal under study, or both.

The total concentration of $\mathrm{Hg}$ in the corals, as well as the $\mathrm{Hg}$ concentration in the zooxanthellae and in the skeleton, was directly related to the $\mathrm{Hg}$ exposure. However, the $\mathrm{Hg}$ concentration in the polyp was higher for colonies at $\mathrm{T}_{0.1}$ than for colonies at $\mathrm{T}_{0.5}$, suggesting that (1) polyp $\mathrm{Hg}$ concentration at $\mathrm{T}_{0.1}$ represents the saturation threshold for $\mathrm{Hg}$ accumulation in this compartment, (2) polyps decreased their metabolic rate and consequently decreased the absorption and accumulation of $\mathrm{Hg}$ at $\mathrm{T}_{0.5}$ and/or (3) detoxifying mechanisms in the polyps began functioning at $\mathrm{T}_{0.5}$ or were more efficient at $\mathrm{T}_{0.5}$ than at other exposure levels. Although these mechanisms may operate simultaneously, our finding that $\mathrm{Hg}$ in the skeleton and in the zooxanthellae were directly related to $\mathrm{Hg}$ exposure supports the suggestion that diversion of heavy metal to these compartments is a potential detoxifying mechanism for the polyp.

The reduction in zooxanthellae density in colonies exposed to Hg may have been a consequence of algae death and/or expulsion of algae from the polyp. We were unable to differentiate between these mechanisms as we did not measure the zooxanthellae density in the water and we did not study the effect of $\mathrm{Hg}$ on isolated zooxanthellae. However, the lack of evidence for either $\mathrm{Hg}$ saturation in the zooxanthellae or reduction in the pigment content per cell suggested that algae expulsion was more likely than algae death. Zooxanthellae expulsion is a general response to several stress factors (reviewed in Jones 1997), and it has been observed in corals exposed to Fe (Harland \& Brown 1989) as well as anemones, corals and clams exposed to $\mathrm{Cu}$ (Howard et al. 1986, Harland \& Nganro 1990, Duquesne \& Coll 1995, Jones 1997). Harland \& Brown (1989) proposed zooxanthellae expulsion as a mechanism of detoxification and our findings are consistent with this hypothesis.

The Hg content in the skeleton of the coral Porites astreoides increased after a few days of exposure. In coral skeletons, metals are found in the skeletal matrix (Shen \& Boyle 1987), as particles deposited over exposed parts of the skeleton (Brown et al. 1991), and/or associated with the trapped organic matter (Budd et al. 1993). In this study, the relative contribution of the organic matter trapped within the skeletal structure after the cleaning procedure was negligible. Thus, the Hg concentrations included the Hg incorporated to the aragonite matrix through new accretion during the bioassays, and the $\mathrm{Hg}$ adsorbed to the skeleton. The high affinity of calcium to heavy metals (e.g. Bjerregaard \& Depledge 1994, Chinchón et al. 2000) and the presence of $\mathrm{Hg}$ in the skeleton suggest that this coral compartment may be an extracellular reservoir for heavy metals, a possibility that deserves further investigation.

In addition, the coral polyps may have eliminated $\mathrm{Hg}$ through the formation of mucus. Mucus sheets, which were often observed during our bioassays, are frequently produced when coral colonies are subjected to stress such as sedimentation (Riegl \& Branch 1995) and their occurrence can be common for Porites astreoides in the field and in laboratory conditions (Bak \& Elgershuizen 1976). Mucus formation has been proposed as a mechanism for detoxification, or at least for reducing the accumulation of various metals, in several organisms including fishes (Varanasi et al. 1975, Pärt \& Lock 1983), nematodes (Howell 1982), bivalves (Sze \& Lee 1995), anemones (Harland \& Nganro 1990), and corals (Brown et al. 1991).

Porites astreoides showed distinct signs of physiological deterioration as a result of $\mathrm{Hg}$ exposure. The polyp biomass, protein content per zooxanthella, and zooxanthellae density decreased and, mostly as a consequence of the latter two, the zooxanthellae protein and pigment content per unit surface area also decreased. Most of these parameters clearly declined in colonies at the highest $\mathrm{Hg}$ exposure, but some of them differed little between the colonies exposed to lower Hg levels and the control colonies. As the 'natural' concentration of $\mathrm{Hg}$ in coastal and estuarine environments ranges between 2 and 15 ppb (Stein et al. 1996), it is possible that the use of 4 and $37 \mathrm{ppb}$ of $\mathrm{Hg}$ in the water was a relatively low level of exposure and precluded measurable physiological changes in the corals. Also, Hg concentrations in the area where corals were collected were < 0.2-0.5 ppb in seawater, 6-129 ppb in surface sediment (García et al. 1998), 161-325 ppb in sediment collected from traps (Bastidas et al. 1999), 19-43 ppb in Thalassia testudinum (Pérez 1995), and 2.03-8.87 $\mu \mathrm{g}$ $\mathrm{g}^{-1}$ in echinoderms (Iglesias \& Penchaszadeh 1983). These Hg levels suggest that the 'baseline' concentrations experienced by our experimental colonies were such that the most distinct changes occurred at the highest concentration. On the other hand, it was only at this $\mathrm{Hg}$ exposure that coral mortality or rapid qualitative changes (polyp retraction, bleaching and tissue loss) occurred in the same sequence as reported for hard corals exposed to 5-20 ppm of diterpens (Aceret et al. 1995), and to 0.01-1 ppm of $\mathrm{Cu}$ (Howard et al. 1986). 
This study contributed to the understanding of Hg accumulation and distribution within corals, using Porites astreoides as a model. The Hg content per unit coral surface area differed between compartments as follows: zooxanthellae > polyp > skeleton for all levels of exposure. Differences in Hg concentration among coral compartments suggest a mechanism by which polyps may divert metal ions to the zooxanthellae or to the skeleton, either as a proper detoxifying mechanism or as a metabolic response. Based on the decline of various biomass parameters of the polyps and of the zooxanthellae, our results indicate that up to $15 \mathrm{~d}$ of exposure to $\mathrm{Hg}$ concentrations of 4 to $180 \mathrm{ppb}$ in water may cause a decline in coral physiological condition, or coral death.

Acknowledgements. We sincerely thank H. Guzmán and P. Zanders, who critically reviewed early versions of this manuscript; C. Peñalosa and J. Cruz, who helped in lab and field activities, respectively; and D. Barnes, S. Patterson, D. Fenner, G. Brunskill, L. Márquez, S. Uthicke, B. Ballment, I. Zagorskis, and J. Heece-Hoyes, for making important suggestions for the $\mathrm{ms}$ in its different versions. Comments from 4 anonymous reviewers also contributed to improve the ms. This work corresponds to the MSc thesis of C.B., who received partial economic support from EcoNatura and from CONICIT. The experiments and coral sample collection complied with the current laws of Venezuela.

\section{LITERATURE CITED}

Aceret TL, Sammarco PW, Coll JC (1995) Toxic effects of alcyonacean diterpenes on scleractinian corals. J Exp Mar Biol Ecol 188:63-78

Allen P (1994) Mercury accumulation profiles and their modification by interaction with cadmium and lead in the soft tissues of the cichlid Oreochromis aureus during chronic exposure. Bull Environ Contam Toxicol 53:684-692

APHA (1992) Cold-vapor atomic absorption spectrophotometric method no. 3112 B. In: Greenberg AE, Clesceri LS, Eaton AD (eds) Standard methods for the examination of water and waste water, 12th edn. American Public Health Association, New York, p 19-22

Bak RPM; Elgershuizen HBW (1976) Patterns of oil-sediment rejection in corals. Mar Biol 37:105-113

Bastidas C, García E (1997) Metal concentration in the tissue and skeleton of the coral Montastrea annularis at a Venezuelan reef. Proc 8th Int Coral Reef Symp, Panama City 2:1847-1850

Bastidas C, García E (1999) Metal content on the reef coral Porites astreoides: an evaluation of river influence and 35 years of chronology. Mar Pollut Bull 38:899-907

Bastidas C, Bone D, García E (1999) Sedimentation rate and metal content in sediments at a Venezuelan reef (Parque Nacional Morrocoy). Mar Pollut Bull 38:16-24

Bianchini A, Gilles R (1996) Toxicity and accumulation of mercury in three species of crabs with different osmoregulatory capacities. Bull Environ Contam Toxicol 57:91-98

Bjerregaard P, Depledge MH (1994) Cadmium accumulation in Littorina littorea, Mytilus edulis and Carcinus maenas: the influence of salinity and calcium ion concentrations. Mar Biol 119:385-395
Blust R, Baillieul M, Decleir W (1995) Effect of total cadmium and organic complexing on the uptake of cadmium by the brine shrimp, Artemia franciscana. Mar Biol 123:65-73

Bradford M (1976) A rapid and sensitive method for the quantitation of microgram quantities of protein utilizing the principle of protein-dye binding. Anal Biochem 72: 248-254

Brown BE, Holley MC (1982) Metal levels associated with tin dredging smelting and their effect upon intertidal reef flats at Ko Phuket, Thailand. Coral Reefs 1:131-137

Brown BE, Howard S (1985a) Responses of coelenterates to trace metals: A field and laboratory evaluation. Proc 5th Int Coral Reef Symp, Moorea 2:465-470

Brown BE, Howard LS (1985b) Assessing the effects of 'Stress' on coral reef corals. Adv Mar Biol 22:1-63

Brown BE, Tudhope AW, Le Tissier MDA, Scoffin TP (1991) A novel mechanism for iron incorporation into coral skeletons. Coral Reefs 10:211-215

Budd AF, Mann KO, Guzmán HM (1993) Environmental interpretation using insoluble residues within reef coral skeletons: problems, pitfalls, and preliminary results. Coral Reefs 12:31-42

Buddemeier RW, Schneider RC, Smith SV (1981) The alkaline earth chemistry of corals. Proc 4th Int Coral Reef Congr, Quezon City 2:81-85

Chinchón S, Auernheimer C, Alastuey S, Gali S (2000) Accumulation of $\mathrm{Pb}$ and $\mathrm{Zn}$ in sea urchin plates and spines related to their different crystalline structure. Mar Pollut Bull 40:647-649

Davies PS (1989) Short-term growth measurements of corals using an accurate buoyant technique. Mar Biol 101: 389-395

Denton GRW, Burdon-Jones C (1986) Trace metals in corals from the Great Barrier Reef. Mar Pollut Bull 17:209-213

Duquesne SJ, Coll JC (1995) Metal accumulation in the clam Tridacna crocea under natural and experimental conditions. Aquat Toxicol 32:239-253

Esslemont G, Harriot VH, McConchie DM (2000) Variability of trace-metal concentrations within and between colonies of Pocillopora damicornis. Mar Pollut Bull 40:637-642

Evans EC (1977) Microscom responses to environmental perturbants. Helgol Wiss Meeresunters 30:178-191

García EM (1993) The ability of the unicellular giant algae Acetabularia sp. to bioconcentrate aquatic mercury in whole and anucleated cells. Toxicol Environ Chem 39:29-35

García EM, Reyes RE (1996) Bioconcentration of $\mathrm{Hg}$ in Acetabularia calyculus: evidence of a polypeptide in whole cells and anucleated cells. Toxicol Environ Chem 55:11-18

García EM, López-Pérez J, Klein E, Morales R (1998) Estudio de parámetros contaminantes de la Costa Oriental del Estado Falcón. Technical Report Gobernación del Estado Falcón, Coro

Gattuso JP, Yellowlees D, Lesser M (1993) Depth- and lightdependent variation of carbon partitioning and utilization in the zooxanthellate scleractinian coral Styllophora pistillata. Mar Ecol Prog Ser 92:267-276

Geffen AJ, Pearce NJG, Perkins WT (1998) Metal concentrations in fish otoliths in relation to body composition after laboratory exposure to mercury and lead. Mar Ecol Prog Ser 165:235-245

Glynn PW, Szmant AM, Corcoran EF, Cofer-Shabica SV (1989) Condition of coral reef cnidarians from the northern Florida reef tract: pesticides, heavy metals, and histopathological examination. Mar Pollut Bull 20:568-576

Goreau TJ (1977) Coral skeletal chemistry: physiological and environmental regulation of stable isotopes and trace met- 
als in Montastrea annularis. Proc R Soc Lond Ser B Biol Sci 196:291-315

Guzmán HM, García EM (2002) Mercury levels in coral reefs along the Caribbean coast of Central America. Mar Pollut Bull 44:1415-1420

Guzmán HM, Jarvis KE (1996) Vanadium century record from Caribbean reef corals: a tracer of oil pollution in Panama. Ambio 25:523-526

Guzmán HM, Jiménez CE (1992) Contamination of coral reefs by heavy metals along the Caribbean coast of Central America (Costa Rica and Panama). Mar Pollut Bull 24:554-561

Hanna RG, Muir GL (1990) Red sea corals as biomonitors of trace metal pollution. Environ Monit Assess 14:211-222

Harland AD, Brown BE (1989) Metal tolerance in the scleractinian coral Porites lutea. Mar Pollut Bull 20:353-357

Harland AD, Nganro NR (1990) Copper uptake by the sea anemone Anemonia viridis and the role of zooxanthellae in metal regulation. Mar Biol 104:297-301

Herut B, Hornung H, Kress N, Cohen Y (1996) Environmental relaxation in response to reduced contaminant input: the case of mercury pollution in the Haifa Bay, Israel. Mar Pollut Bull 32:366-373

Howard LS, Brown BE (1984) Heavy metals and reef corals. Oceanogr Mar Biol Annu Rev 22:195-210

Howard LS, Brown BE (1987) Metals in Pocillopora damicornis exposed to tin smelter effluent. Mar Pollut Bull 18: 451-454

Howard LS, Crosby DG, Aliño P (1986) Evaluation of some methods for quantitatively assessing the toxicity of heavy metals to corals. In: Jokiel PL, Richmond RH, Rogers RA (eds) Coral reef population biology. Technical Report No. 37. Hawaii Institute of Marine Biology, Coconut Island, p 452- 464

Howell R (1982) The secretion of mucus by marine nematodes (Enoplus spp.): a possible mechanism influencing the uptake and loss of heavy metal pollutants. Nematologica 28:110-114

Iglesias N, Penchaszadeh P (1983) Mercury in sea stars from Golfo Triste, Venezuela. Mar Pollut Bull 14:396-398

Jackson ML (1970) Análisis químico de suelos, 2nd edn. Ediciones Omega, Barcelona

Johannes RE, Wiebe WJ (1970) Method for determination of coral tissue biomass and composition. Limnol Oceanogr 15:822-824

Jones RJ (1997) Zooxanthellae loss as a bioassay for assessing stress in corals. Mar Ecol Prog Ser 149:163-171

Lacher TE, Goldstein MI (1997) Tropical ecotoxicology: status and needs. Environ Toxicol Chem 16:100-111

Lesser M, Shick JM (1989) Effects of irradiance and UV radiation on photoadaptation in the zooxanthellae of Aiptasia pallida: primary production, photoinhibition, and enzymic defenses against oxygen toxicity. Mar Biol 102:243-255

Lesser M, Stochaj WR, Tapley DW, Shick JM (1990) Bleaching in coral reef anthozoans: effects of irradiance, ultraviolet radiation, and temperature on the activity of protective enzymes against active oxygen. Coral Reefs 8:225-232

Lewis MA (1995) Algae and vascular plant tests. In: Rand GM, Petrocelli SR (eds) Fundamentals of toxicology: effects, environmental fate and risk assessment, 2nd edn. Taylor \& Francis, Washington, DC

Marsh AJ Jr (1970) Primary productivity of reef-building calcareous red algae. Ecology 51:255-263

McAuley PJ (1986) Isolation of viable uncontaminated Chlorella from green hydra. Limnol Oceanogr 31:222-224

Miller DJ, Yellowlees D (1989) Inorganic nitrogen uptake by symbiont marine cnidarians: a critical review. Proc R Soc Lond Ser B Biol Sci 237:109-125
Mitchell R, Chet I (1975) Bacterial attack of corals in polluted seawater. Microb Biol 2:227-233

Morel FM, Kraepiel AML, Amyot M (1998) The chemical cycle and bioaccumulation of mercury. Annu Rev Ecol Syst 29:543-566

Palmer SJ, Presley BJ (1993) Mercury bioaccumulation by shrimp (Peaneus aztecus) transplanted to Lavaca Bay, Texas. Mar Pollut Bull 26:564-566

Palmer SJ, Presley BJ (1996) Mercury concentrations in benthic organisms from a contaminated estuary. Mar Environ Res 41:225-239

Parsons TR, Strickland JDH (1963) Discussion of spectrometric determination of marina-plant pigments, with revised equations for ascertaining chlorophylls and carotenoids. J Mar Res 21:155-163

Pärt P, Lock RAC (1983) Diffusion of calcium, cadmium and mercury in a mucous solution from rainbow trout. Comp Biochem Physiol 76C:259- 263

Pérez D (1995) Mercurial pollution in the seagrass Thalassia testudinum (Banks ex Koning). Bull Mar Sci 56:707-710

Pergent G, Pergent-Martini C (1999) Mercury levels and fluxes in Posidonia oceanica meadows. Environ Pollut 106: $33-37$

Peters EC, Gassman NJ, Firman JC, Richmond RH, Power EA (1997) Ecotoxicology of tropical marine ecosystems. Environ Toxicol Chem 16:12-40

Rand GM, Wells PG, McCarty LS (1995) Introduction to aquatic toxicology. In: Rand GM, Petrocelli SR (eds) Fundamentals of toxicology: effects, environmental fate and risk assessment, 2nd edn. Taylor \& Francis, Washington, DC

Riegl B, Branch GM (1995) Effects of sediment on the energy budgets of four scleractinian (Bourne 1900) and five alcyonacean (Lamouroux 1816) corals. J Exp Mar Biol Ecol 186:259-275

Rossi A, Pellegrini D, Belcari P, Barghigiani C (1993) Mercury in Eledone cirrhosa from the Northern Tyrrherian Sea: contents and relation with life cycle. Mar Pollut Bull 26: 683-686

Schlichter D, Fricke HW (1991) Mechanisms of amplification of photosynthetically active radiation in the symbiotic deep-water-coral Leptoseris fragilis. Hydrobiologia 216/ 217:389-394

SCOR-UNESCO (1966) Determination of photosynthetic pigments in sea water. Monograph 1, UNESCO, Paris

Scott PJB (1990) Chronic pollution recorded in coral skeletons in Hong Kong. J Exp Mar Biol Ecol 139:51-64

Shen GT, Boyle EA (1987) Lead in corals: reconstruction of historical industrial fluxes to the surface ocean. Earth Planet Sci Lett 82:289-304

Shen GT, Boyle EA, Lea DW (1987) Cadmium in corals as a tracer of historical upwelling and industrial fallout. Nature 328:794-796

Sorensen M, Bjerregaard P (1991) Interactive accumulation of mercury and selenium in the sea star Asterias rubens. Mar Biol 108:269-276

Stein ED, Cohen Y, Winer AM (1996) Environmental distribution and transformation of mercury compounds. Environ Sci Technol 26:1-43

Strickland JDH, Parsons TR (1977) A practical handbook of seawater analysis, 2nd edn. Fisheries Research Board of Canada, Ottawa

Sze PCW, Lee SY (1995) The potential role of mucus in the depuration of copper from the mussels Perna viridis (L.) and Septifer virgatus (Wiegmann). Mar Pollut Bull 31:390-393

Varanasi U, Robisch PA, Malins DC (1975) Structural alterations in fish epidermal mucus produced by water-borne lead and mercury. Nature 258:431-432 